\title{
The Concrete Embodiment of Hierarchy in Thailand's Society and Its Analysis
}

\author{
Zhaoyang Duan \\ Yunnan Normal University \\ Kunming, China
}

\begin{abstract}
Thai society has a strict hierarchy, which reflects in the absolute obedience especially to the king and the royal family, ranging from the civil and military officials to the civilians. In front of the king and the royal family, the kneeling ceremony must also be carried out, which is the highest etiquette in Thailand. In addition, Thai language can be divided into general terms, Buddhist terms and royal terms. General terms are Thai people's daily terms. Buddhist terms are related to Buddhist, Buddhism and monks. Royal terms are exclusively used by the king and royal family. For example, Royal terms are used for eating, wearing, living, traveling, using, or life circle and body parts, etc. It can be seen from the above-mentioned language and behavior that Thailand is a strictly hierarchical country, and the specific reason for Thailand's hierarchy is mainly influenced by Brahmanism and Buddhism. Since the democratic revolution in 1932, Thailand's political system has changed from autocratic monarchy to constitutionalism, which is an inevitable process of social development and progress. In other words, the Thai society is developing towards the trend of diversification. However, the idea of "Divine Right of Kings" has been deeply rooted in the heart of the people, thus the etiquette of kneeling and the culture of using Royal terms exist till today.
\end{abstract}

Keywords-Thai language; concept of social hierarchy; Brahmanism; Divine Right of Kings

\section{INTRODUCTION}

Thailand's culture has a wide range of high and low, which is commonly known as hierarchical relations. The range of high-low distinction covers a wide range, including all levels of positions, ages and qualifications between nobles and civilians. In Thailand's concept of hierarchy, those who are holding high positions need to respect and submit to those who are holding higher positions. In general this phenomenon is reflected in three parts: First, Respect; Second, Obedience; Third, Humility. "Respect" means to follow the right etiquette in words and deeds; "Obedience" refers to follow the opinions of "adults" and act according to their willingness. "Humility" is not only to obey but also to show the humility. If these customs are violated, they will be strongly condemned by the society. In daily life, this kind of "hierarchical concept" still regulates the Thai people's words and manners of all time and dominates the Thai people's behaviors. "Hierarchical concept" is not only a question of a concept, but also a recognized standard of people's daily behaviors, and even a "way of life". If Thai people meet each other, they will receive Namaste. However, when they see the king, they must kneel, which is the respect, worship and obedience for the king.

\section{THE CONCRETE EMBODIMENT OF SOCIAL RANK IN THAILAND}

\section{A. "Kneeling Ceremony" Etiquette}

Thai society has a strict hierarchy, especially in the absolute obedience of the people to the king and the royal family, ranging from the civil and military officials to the civilians, who also have to kneel in front of the king and the royal family. The kneeling ceremony in Thailand has been continued from ancient times till now. "Kneeling ceremony" is not only used for the worship for the king and the royal family by the civil and military officials and the common people, but also for the monks and priests, the students for the teachers, and the children for their parents and elders. The common posture of kneeling is to put on the ground with two elbows, two palms and forehead, and then lie on the ground with two palms together. This kneeling is the highest etiquette in Thailand. The Thai people kneel to the king and the royal family, which reflects the Thai people's respect and worship for the king and the royal family, absolute obedience to the king and the royal family, and also reflects the hierarchy of Thai's society.

\section{B. The Use of Royal Language}

"There is something behind the language, and language cannot exist without culture." said Edward Sapir, an American linguistics professor. Another anthropologist, E.B. Tylor, also said: "culture is 'a complex entity', including knowledge, belief, art, morality, law, custom and all other abilities acquired by a person as a member of society." Language is the carrier of culture and a mirror reflecting a national culture. Language is not only a form of cultural expression, but also a social and cultural phenomenon. The Royal language in Thailand obviously shows the people's respect and worship for the king in Thai culture, and also reflects the concept of hierarchy in Thai society, which is, the king is the head of state, in the highest level of Thai society. Therefore, the language used by the king and the royal family is different from that of the ordinary people.

Thai language is divided into general terms, Buddhist terms and royal terms. General terms are the daily 
In 1431, after Thailand invaded Angkor Wat, the idea of "Divine Right of Kings" was accepted by the rulers and introduced into the court, which greatly influenced the formation of Thai feudal system. The idea of "Divine Right of Kings" also made the Thais think that the king and the nobles had the noble blood, thus the high, medium and low social level was formed. The Brahmanic idea of "Divine Right of Kings" made them support the King, who was the political core of ancient Thailand. Plus in ancient times, people didn't have the awareness of rights and equality, therefore the King's proposal was allowed to go without any resistance and doubt.

\section{2) Influences by Buddhism:}

The majority of Thai people believes in Buddhism, and the Buddhist doctrines are as follows: "what we have in this life is caused by what we did in the previous life; what we are doing in this life will affect our next life," which make the Thais believe that the good life of the superior is the result of the virtue accumulated in the previous life, and the suffering of the inferior is the result of the sin from their previous life, which is difficult to be changed through the efforts of the present life. As a result, most Thais, especially the lower class, adhere to the undisputed attitude of obedience and tolerance, which helps avoid unnecessary conflicts against the unequal system and disputes.

\section{3) Affected by land ownership:}

In the primitive farming society, the status of land is very high. Land is the most important material of production and symbol of wealth. People's food comes from the land, even build social status and prestige by accumulating wealth through crop production. The idea that land is the symbol of wealth makes the ownership of land valuable more than ever. In order to protect their own interests and property from threats, the upper class society gradually formed the "Sadina" system.

The reasons for the formation of social hierarchy in Thailand's feudal period can be divided into two categories. The first category is mainly spiritual factors, which are influenced by Brahmanism's hierarchical concept, the concept of "Divine Right of Kings" and Buddhism's concept of "Retribution for Sin", they were divided into high-low class at the beginning. When facing the suffering and oppression, most people choose to endure and obey, even support their spiritual leaders, the King, thus the social hierarchy of Thailand came into being. The second category is the economic factor. In the primitive farming society, land was almost all economic sources. Having land meant having wealth, social status and higher position. Therefore, land had become a thing the upper class people fought for. Therefore, "Sadina" system had been created to protect the rights of the upper class people, which embodied the social class of Thailand vividly. 
the people and prevent the country from being split. However, the Buddhist concept of "Reincarnation" (previous and current life) makes people take all tribulations and misfortunes for granted. They treat the powerful people respectfully, which forms the awe of the King and official's power, and the obedience to the authority. This has formed a habit of obeying the superior and dare not resist the privilege which is not favorable to the social development and progress.

In conclusion, there are two reasons for the change of social hierarchy during the period of Thailand's democratic system. One is the internal factor, which is the civil officials who went to the western countries to study and were influenced by the western democratic ideas. Meanwhile the major social elites were also willing to accept the political transformation of Thailand to protect the country's independence. Thailand is a country with a long history of patronage system plus Buddhism encourages people to endure unfairness, therefore the Thais have to accept the reform proposals of their superiors. The other factor is from the external matter. Back in the 19th century, due to the threat of Western powers, the rulers sensed the national crisis, and had been constantly exploring solutions for the crisis. Later on, after the contact between the Thais and the westerners, their ideas had changed and begun to awaken. After the democratic revolution, during 1932-1940, the policy of "attaching importance to the city and neglecting the countryside" of the Pibul government has led to the emergence of the urban class and the diversification of the social class.

\section{CONCLUSION}

After the democratic revolution in 1932, the hierarchy system collapsed formally, but still exists in reality. But from Chinese businessmen to the rise of political and commercial groups in Bangkok, from local powerful heads to political corporation, other political powers have gradually grown up in Thai politics. With the continuous improvement of farmers' demands for the rights of political discourse drives the political pattern more diversified, which makes the class difference less and less obvious, as well as gradually reduces the gap between the rich and the poor. From the feudal period to the modern democratic period, the Thai society is constantly improving, the social class is constantly reduced, the political economy and culture are also non-stop developing and improving, and the people's living standards are steadily improving. However, the idea of "Divine Right of Kings" has been deeply rooted in the people's mind, thus the etiquette of kneeling and the culture of using Royal language still exist.

\section{REFERENCES}

[1] Changpei Luo, Language and Culture[M], Jiangxi: Jiangxi Education Publishing House, 2018

[2] Fangzhi Zhou, Monarchy, Authority, Plutocracy - The process of Political Modernization of Thailand $[\mathrm{M}]$, Beijing: Social Sciences Academic Press, 2011.10
Thai people has never been changed, and it impacts Thai politics both positively and negatively. More than $90 \%$ of the people in Thailand believe in Buddhism, which helps unite 
[3] Zhaohui Yi, Overview of Thailand [M], (2003 Edition), Chongqing: Chongqing University Press, 2013.5

[4] Zhenming Zhu, Contemporary Thailand[M], (1992 Edition), Sichuan: Sichuan People's Publishing House, 1992.7

[5] Lisheng Duan, The History of Thailand[M], (2014 Edition), Shanghai: Shanghai Academy of Social Sciences Press, 2014.12

[6] Edited by Guangzhou Foreign Language Shcool, Thai-Chinese Dictionary[Z], Beijing: The Commercial Press, 2001

[7] Jittima Anansakulcharoen. (2015). Class and Period of Thai Politics and Government [M]. P. 8-9.

[8] Phisit Wongsaratsil. (2017). Public opinion on democracy. In Mueang Nonthaburi District Nonthaburi Province [J]. P. 9

[9] Sikan Phianthanyakon. (2014). The Causal Relationship Model of Variables Affecting Public Mental Behavior Level of Thai Youth in Sakon Nakhon Province [J]. P.14 